\title{
Study on the Influence of Water Physico Chemical Properties on Phytoplankton Population in Kirumampakkam and Korkadu Lakes, Pondicherry Region, India
}

\author{
Sudhakaran Mani ${ }^{\text {** }}$, Ramamoorthy Duraisamy ${ }^{1}$, \\ Savitha Veeraragavan ${ }^{1}$ and Rajesh Ramasamy ${ }^{2}$ \\ ${ }^{1}$ Department of Ecology and Environmental Sciences, Pondicherry University, \\ Puducherry 605 014, India \\ ${ }^{2}$ Department of Agricultural Microbiology, Tamil Nadu Agricultural University, \\ Coimbatore 641 003, Tamil Nadu, India \\ *Corresponding author
}

\section{A B S T R A C T}

\section{Keywords \\ Phytoplankton, \\ Diversity, Lake \\ ecosystem and \\ physico-chemical \\ properties.}

Article Info

Accepted:

24 September 2017

Available Online:

10 November 2017
The objectives of our research were to determine the influence of water physico chemical properties on phytoplankton population of two lake ecosystem (Kirumambakkam and Korkadu), Pondicherry region. Sulphate, Organic Carbon (OC), phosphate, sodium, potassium, DO, salinity and TDS were higher in Kirumamabakkam lake water samples. Ammonia, nitrate and BOD were higher in Korkadu lake water samples. During the study period 13 species of phytoplanktons were represented by diverse groups Chlorococcales (4), Volvvocales (3), Oscillatoriales (2), Euglenales (1), Nostocales (1) and Pennales (1). Population density ranged between 60 to 270 cells/l in Kirumamabakkam and Korkadu lakes. Closterium sp. was higher diversity in both lakes.

\section{Introduction}

Water is a necessary element for endurance of living on earth, which contains minerals, essential for humans as well as for earth and aquatic life industrial infrastructures and agriculture complexes have been built up in vicinity of rivers and other water bodies (Varis 1991). Lake, a large body of water surrounded by land and inhabited by various aquatic life forms, is subjected to various natural processes taking place in the environment and anthropogenic activities. Humans are responsible for choking several lakes to death due to a consequence of unprecedented development. Eutrophication is accelerated as a result of human activities near or in a body of water that generate residential wastes, untreated or partially treated sewage, agricultural runoff and urban pollutants (Sarma et al., 2006). The major sources of nitrate in lakes and ponds are from the catchment area by rainfall, sewage effluents, agro waste, suspended organic matter when algae and other suspended microorganisms die and settle down to the 
bottom. They carry their nitrogen and phosphorous with them, during decomposition. This nitrogen is released and becomes available for subsequent growth of aquatic biota. Orthophosphate is the soluble reactive phosphorous which is also termed as inorganic phosphate. It plays a dynamic role in aquatic ecosystem which is taken up widely by phytoplankton (Rey et al., 2004).

The phytoplankton is the base of most of the lake food webs and fish production is linked to phytoplankton (Ryder, 1974). Phytoplankton and micro invertebrates which in turn provide food to fishes and aquatic birds. Planktonic primals in fresh water are dominated by rotifers cladocerans and copepods. Rotifers are most sensitive bioindicators of water quality and their presence may be used as a reference to the physico-chemical characteristics of water (Harsha and Malammanavar 2004). Phytoplankton form good indicators of water quality as they have rapid turn-over time and are sensitive indicators of environmental stresses. Phytoplankton survey thus helps to find out the trophic status and the organic pollution in the ecosystem. Phytoplankton constitutes the basis of nutrient cycle of an ecosystem. Phytoplanktons have long been used as indicators of water quality. Because of their short life cycles, planktonic organisms respond quickly to environmental changes and hence their standing crop and species composition indicate the quality of water (Perumal et al., 2009). Phytoplanktons are affected by physical, chemical and biological factors, making them valuable tool in monitoring programmes. On the basis of this, many workers have emphasized that algal communities as a whole serve as reliable indicators of pollution (Rojoand Rodríguez 1994; Soininen, et al., 2009; Reavie et al., 2010). This study were conducted to determine the nutrient status and influence of water physico chemical properties on phytoplankton population of two lake ecosystem (Kirumambakkam and Korkadu) which is lying to industrial as well as anthropogenic pressure.

\section{Materials and Methods}

\section{Study area}

Pondicherry is located along the Coramandel coast of peninsular India with the geographical coordinates $11^{0} 52^{\prime} \mathrm{N}, 79^{0} 45^{\prime} \mathrm{E}$ and $11^{\circ} 59^{\prime} \mathrm{N}$ and $79^{\circ} 52^{\prime} \mathrm{E}$ covering an area of $480 \mathrm{~km}$. The mean annual rainfall of the study area is about $1311-1172 \mathrm{~mm}$. The mean number of annual rainy days is 55; the mean monthly temperature ranges between $21^{0} \mathrm{C}$ and $30^{\circ} \mathrm{C}$ in the study area. The Puducherry region is bestowed with 83 tanks which scattered in all over the region usually fills up during the North East Monsoon. The study site, Kriumambakkam Lake (site 1, 2 and 3) and Korkadu (site 4, 5 and 6) were located 25 $\mathrm{km}$ away from the town. In the back drop of depletion of ground water table, water is stored in the tanks for replenishing the ground water. In such way, tanks are serving only as a recharging mechanism by which groundwater table have enhanced considerably simultaneous with the prevention of intruding seawater in to sweet water aquifers. Paddy is the principal crop amongst all the crops cultivated in the wet land for three crop season irrigated my means of tube wells. Ponds exist in all over Puducherry region but they are not used for agricultural activities.

\section{Methodology}

Water samples were collected from December-2013 to July - 2014 for the purpose of water physico chemical and trace element analysis. Phytoplankton samples were collected by towing a plankton net (mouth diameter $0.35 \mathrm{~mm}$ ) made up of bolting silk (no.30; mesh size $48 \mu$ ) for half an hour. The samples were collected in black polythene 
bags and immediately preserved with 4\% formalin for quantitative and qualitative analysis. Plankton counting was made by drop method. Specimens were then dehydrated through a graded series of acetone 12-15 min interval at $4^{\circ} \mathrm{C}$ up to $70 \%$ of acetone and dispense $1 \mathrm{~mL}$ of the sample onto the Sedgewick-Rafter counting chamber. They were examined with face contrast microscope. Phytoplankton was identified by standard reference given in Desikachary (1959) and Anand (1998). Species diversity index (H') was calculated using Shannon and Weiner's (1949) and Pielous (1966) formulae respectively. Species richness (SR) was calculated as described by Simpson index.

For the study of physico-chemical analysis water samples were collected from the pond surface in a clean polythin container of one litre capacity. Some of the results were recorded at the sampling sites whereas the others were recorded in the laboratory. The parameters observed were $\mathrm{pH}, \mathrm{EC}$ (Electrical conductivity), DO, BOD. TDS, Alkalinity, salinity, Ammonia, OC (Organic Carbon), Nitrate, Phosphate, Sulphate, sodium, potassium and trace elements. The analytical procedures adopted for the analyses of water quality were as detailed in the standard methods for examination of water and waste water (APHA, 2006).

\section{Results and Discussion}

\section{Water Physico-chemical properties}

Hydrogen ion concentration plays an important role in the biological process of almost all aquatic organisms. The average $\mathrm{pH}$ of surface water of the kirumbakkam and korkad lakes from 7.95 to 9 . The water tends to be more alkaline when it possesses carbonates, but lesser alkaline when it supports more bicarbonates, free $\mathrm{CO}_{2}$ and calcium (Omstedt et al., 2010). The average
EC surface water of two lakes were ranged from 1.06 to $1.47 \mathrm{~ms} / \mathrm{cm}$. due to dilution factor of precipition the EC decreases as the monsoon pickup (Chari and Abbasi, 2002). The highest EC value recorded in Kirumambakkam Lake Water. The dissolved oxygen concentration was found in of 4.1 to $5.8 \mathrm{mg} / \mathrm{l}$ the higher concentration was recorded at Kirumambakkam Lake.

Dissolved oxygen is an important constituent of water and its concentration in water is an indicator of prevailing water quality and ability of water body to support a wellbalanced aquatic life. DO raised to its peak value, and it might be due to high rate of photosynthesis by phytoplankton population that forms the major source of DO (Sharma and Rathore, 2000). The lowest DO concentration observed at the lower reaches might be because of the influence of salinity, temperature, conductivity, currents and upwelling tides. The regional distribution of biological oxygen demand in between two lakes varied from 1.8 to $2.8 \mathrm{mg} / \mathrm{l}$. the total dissolved solids salts were recorded at the different sites ranging from 539 to $750 \mathrm{mg} / \mathrm{l}$. the highest value of TDS was found at both lakes $(750 \mathrm{mg} / \mathrm{l})$. High value EC designates pollution status of the lake (Davis, 1975) (Table 1). The salinity was found at different sites ranging from 1840 to $2560 \mathrm{mg} / \mathrm{l}$. the highest salinity was found at the site of Korkadu Lake. The highest ammonium concentration was recorded at the site of Kirumambakkam site $3(0.52 \quad \mathrm{mg} / \mathrm{l})$. Ammonium $\left(\mathrm{NH}_{4}{ }^{+}\right)$represented $80 \%$ of Dissolved Inorganic Nitrogen (DIN) and its highest values were always associated with fresh water inflow (Martin et al., 2008). Sankaranarayanan and Qasim (1969) suggested that the spatial and temporal variation in ammonia concentration might also be due to its oxidation to other forms or reduction of nitrates to lower forms in lake waters. 
Table.1 Physico-chemical properties of Kirumambakkam and Korkadu lakes water samples

\begin{tabular}{lllllll}
\hline \multirow{2}{*}{\multicolumn{1}{c}{ Water parameters }} & \multicolumn{3}{c}{ Kirumambakkam lake } & \multicolumn{3}{c}{ Korkadu lake } \\
\cline { 2 - 7 } Site 1 & \multicolumn{1}{c}{ Site 2} & \multicolumn{1}{c}{ Site 3 } & \multicolumn{1}{c}{ Site 4 } & \multicolumn{1}{c}{ Site 5 } & \multicolumn{1}{c}{ Site 6 } \\
\hline $\mathrm{pH}$ & $8.82 \pm 0.01$ & $9 \pm 0.03$ & $8.77 \pm 0.02$ & $9.4 \pm 0.02$ & $8.8 \pm 0.01$ & $7.95 \pm 0.03$ \\
$\mathrm{DO}(\mathrm{ms} / \mathrm{cm})$ & $1.14 \pm 0.01$ & $1.45 \pm 0.04$ & $1.46 \pm 0.04$ & $1.47 \pm 0.02$ & $1.13 \pm 0.03$ & $1.06 \pm 0.02$ \\
$\mathrm{BOD}(\mathrm{mg} / \mathrm{l})$ & $5.8 \pm 0.9$ & $4.1 \pm 0.3$ & $5.3 \pm 0.5$ & $4.1 \pm 0.1$ & $4.2 \pm 0.8$ & $4.1 \pm 0.3$ \\
Salinity $(\mathrm{mg} / \mathrm{l})$ & $1.9 \pm 0.08$ & $2.1 \pm 0.09$ & $1.8 \pm 0.02$ & $2.8 \pm 0.07$ & $2.1 \pm 0.04$ & $2.6 \pm 0.07$ \\
TDS $(\mathrm{mg} / \mathrm{l})$ & $1960 \pm 12$ & $2530 \pm 11$ & $2540 \pm 13$ & $2560 \pm 23$ & $1970 \pm 26$ & $1840 \pm 28$ \\
Organic carbon $(\mathrm{mg} / \mathrm{l})$ & $580 \pm 12$ & $740 \pm 13$ & $750 \pm 14.2$ & $750 \pm 15.8$ & $573 \pm 11.2$ & $539 \pm 11$ \\
Ammonia $(\mathrm{mg} / \mathrm{l})$ & $7.64 \pm 0.09$ & $7.19 \pm 0.06$ & $7.55 \pm 0.07$ & $7.74 \pm 0.02$ & $7.10 \pm 0.80$ & $7.05 \pm 0.09$ \\
Phosphate $(\mathrm{mg} / \mathrm{l})$ & $0.51 \pm 0.01$ & $0.51 \pm 0.01$ & $0.52 \pm 0.03$ & $0.50 \pm 0.02$ & $0.50 \pm 0.01$ & $0.50 \pm 0.02$ \\
Sulphate $(\mathrm{mg} / \mathrm{l})$ & $0.31 \pm 0.01$ & $0.30 \pm 0.01$ & $0.30 \pm 0.01$ & $0.28 \pm 0.01$ & $0.28 \pm 0.01$ & $0.28 \pm 0.01$ \\
Sodium $(\mathrm{mg} / \mathrm{l})$ & $39.29 \pm 1.20$ & $30.11 \pm 1.30$ & $30.99 \pm 0.90$ & $19.07 \pm 1.10$ & $23.50 \pm 0.98$ & $24.13 \pm 1.02$ \\
& $1073 \pm 20$ & $1222 \pm 28$ & $1355 \pm 24$ & $1055 \pm 15$ & $1106 \pm 16$ & $1163 \pm 13$ \\
\hline
\end{tabular}

Table.2 Phytoplankton’s identified in Kirumambakkam and Korkadu lakes water

\begin{tabular}{ll}
\hline \multicolumn{1}{c}{ Order } & \multicolumn{1}{c}{ Species } \\
\hline Chlorococcales & Chlorella $s p$. \\
Chroococcales & Chroococcus sp. \\
Chroococcales & Microcystis sp. \\
Chroococcales & Microcystis sp. \\
Conjucales & Closterium $s p$. \\
Euglenales & Euglena $s p$. \\
Nostocales & Anabaena $s p$. \\
Oscillatoriales & Oscillatoriasp \\
Oscillatoriales & Spirulina sp. \\
Pennales & Navicula sp. \\
Volvvocales & Chlamydomonas sp. \\
Volvvocales & Eudorina sp. \\
Volvvocales & Volvox sp. \\
\hline
\end{tabular}

Table.3 Phytoplankton's population in Kirumambakkam Lake

\begin{tabular}{lcccc}
\hline Phytoplankton's sp & $\begin{array}{c}\text { Density } \\
(\text { cells/l) }\end{array}$ & Frequency & $\begin{array}{c}\text { Relative density } \\
(\%)\end{array}$ & $\begin{array}{c}\text { Relative frequency } \\
(\%)\end{array}$ \\
\hline Anabaena sp. & 200 & 6 & 10.93 & 8.96 \\
Chlamydomonas sp. & 190 & 5 & 10.38 & 7.46 \\
Chlorella sp. & 130 & 5 & 7.10 & 7.46 \\
Chroococcus sp. & 90 & 4 & 4.92 & 5.97 \\
Closterium sp. & 270 & 7 & 14.75 & 10.45 \\
Eudorina sp. & 170 & 8 & 9.29 & 11.94 \\
Euglena sp. & 120 & 5 & 6.56 & 7.46 \\
Microcystis sp. & 80 & 5 & 4.37 & 7.46 \\
Microcystis sp. & 80 & 4 & 4.37 & 5.97 \\
Navicula sp. & 170 & 4 & 9.29 & 5.97 \\
Oscillatoria sp. & 170 & 5 & 9.29 & 7.46 \\
Spirulina sp. & 60 & 2 & 3.28 & 2.99 \\
Volvox sp. & 100 & 7 & 5.46 & 10.45 \\
\hline
\end{tabular}


Table.4 Phytoplankton's population in Korkadu Lake

\begin{tabular}{lcccc}
\hline Phytoplankton's sp & $\begin{array}{c}\text { Density } \\
(\text { cells/l) }\end{array}$ & Frequency & $\begin{array}{c}\text { Relative density } \\
(\%)\end{array}$ & $\begin{array}{c}\text { Relative frequency } \\
(\%)\end{array}$ \\
\hline Anabaena sp. & 170 & 5 & 11.41 & 8.62 \\
Chlamydomonas sp. & 150 & 5 & 10.07 & 8.62 \\
Chlorella sp. & 90 & 2 & 6.04 & 3.45 \\
Chroococcus sp. & 110 & 7 & 7.38 & 12.07 \\
Closterium sp. & 270 & 7 & 18.12 & 12.07 \\
Eudorina sp. & 50 & 2 & 3.36 & 3.45 \\
Euglena sp. & 60 & 3 & 4.03 & 5.17 \\
Microcystis sp. & 60 & 4 & 4.03 & 6.90 \\
Microcystis sp. & 90 & 3 & 6.04 & 5.17 \\
Navicula sp. & 120 & 6 & 8.05 & 10.34 \\
Oscillatoria sp & 170 & 5 & 11.41 & 8.62 \\
Spirulina sp. & 60 & 2 & 4.03 & 3.45 \\
Volvox sp. & 90 & 7 & 6.04 & 12.07 \\
\hline
\end{tabular}

Table.5 Phytoplankton's diversity indices of Kirumambakkam and Korkadu Lakes

\begin{tabular}{llcc}
\hline S. no & Diversity indices & Kirumambakkam lake & Korkadu lake \\
\hline 1. & Richness & 13 & 13 \\
2. & Dominance & 0.09003 & 0.09788 \\
3. & Simpson & 0.91 & 0.9021 \\
4. & Shannon & 2.481 & 2.442 \\
5. & Evenness & 0.9194 & 0.8841 \\
6. & Brillouin & 2.344 & 2.283 \\
7. & Menhinick & 0.961 & 1.065 \\
8. & Margalef & 2.303 & 2.398 \\
9. & Equitability & 0.9672 & 0.952 \\
10. & Fisher & 3.199 & 3.425 \\
11. & Berger-Parker & 0.1475 & 0.1812 \\
\hline
\end{tabular}

The Nitrate was recorded at the different sites ranging from 3.93 to $4.15 \mathrm{mg} / \mathrm{l}$. the highest concentration of nitrate was recorded in site 1 of Kirumambakkam Lake. Nitrogen cycle involves elementary dissolved nitrogen oxides; $\mathrm{NO}_{3}, \mathrm{NO}_{2}$ and reduced forms: $\mathrm{NH}_{4}$, $\mathrm{NH}_{3}$ play a significant role in sustaining the aquatic life in marine environment. Nitrate is one of the most important indicators of pollution of water which represents the highest oxidized form of nitrogen. The most important source of the nitrogen is biological oxidation of organic nitrogenous substances, which derived from sewage and industrial waste or produced indigenously in the water (Sharma et al., 2008). Zepp (1997) observed that variation in nitrate and its reduced inorganic compounds are predominantly the result of biologically activated reactions. In our study, both lake sites show slightly higher phosphate values than the WHO permissible limit $(0.10 \mathrm{mg} / \mathrm{l})$. The major cause for phosphate concentration in the lakes might be the agricultural run from the irrigated lands containing phosphate fertilizer. Gabche and Smith (2002) while working on two estuaries 
of Cameron concluded that the increased concentration of phosphate after monsoon was the result of agricultural run-off along with city drainage which in-turn will serve as important phosphate contributors to the coastal environment.

\section{Phytoplankton's population}

During the study period 13 species of phytoplanktons were represented by diverse groups Chlorococcales (4), Volvvocales (3), Oscillatoriales (2), Euglenales (1), Nostocales (1) and Pennales (1). Population density ranged between 60 to 270 cells $/ 1$ in Kirumamabakkam and Korkadu lakes. Closterium sp. was higher diversity in both lakes (Tables 2-5). Phytoplankton population was higher in the Kirumambakkam due to presents of higher nutrient content in water. Joseph and Ouseph (2010), states that diatom growth is dependent on supplies of available silica, which tends to decrease with phosphorus enrichment. Thus, the high concentrations of Nitzschia during study period are favored by the relatively low concentrations of phosphates. Jouenne et al., (2007) stated that phytoplankton composition varies with season and this can be ascribed to variation in nutrient access, light and temperature. Rey et al., (2004) suggested that besides their importance as the primary producers in food webs and ensuring ecological balances, species of phytoplankton can be useful indicators of water quality. Phytoplankton needs a wide variety of chemical elements but the two critical ones are nitrogen and phosphorous. Constant input of wastewater not only contains waste of organic matter but also contains silt and other pollutants which might also be attributed to higher phytoplankton at upper reaches, this is in agreement with Saxena and Shrivastava (2001), while studying the sewage fed Shahpura Lake of Bhopal. Muhammad et al., (2005) have suggested spatial differences in distribution of blue green algae which may occur due to high organic pollution load leading to nutrient rich condition.

The present study summarizes the influence of water physico chemical properties on phytoplankton population in Kirumampakkam and Korkadu lakes. The addition of nitrogenous compounds and phosphorus compounds from anthropogenic sources such as fertilizer output, as an effect of industrialization and from agricultural runoff in the Kirumambakkam Lake. From the present investigation it could be noted that the phytoplankton population of the Kirumamabakkam and korkadu lakes were closely related with physico chemical properties. Dynamic changes in $\mathrm{pH}$, and concentrations of dissolved gases like oxygen, organic carbonand inorganic nutrients (nitrate, phosphate and sulphate) are all closely associated with fluctuations in phytoplankton composition. The overall study provides a good outline on the prevailing condition of the two lakes ecosystem.

\section{Acknowledgement}

The authors are grateful towards the department of Ecology and Environmental Science, Pondicherry University for providing laboratory facilities in order to conduct the experiment. They extend their gratitude to Central Instrumentation Facility, Pondicherry University for element analysis.

\section{References}

Anand, N.: 1998. Indian freshwater microalage. Bishen Sing Mahendrapal Singh Publishers. p. 94

APHA. 2006. Standard methods for the examination of water and wastewater, $21^{\mathrm{st}}$ Edn. APHA, AWWA, WPCF, Washington, DC, USA

Chari, K.B and Abbasi S.A. 2003. Fish fauna 
of Oussudu Lake, Pondicherry, South India. Indian J. Fish., 50(1): 97-101.

Davis, J.C., 1975. Minimal dissolved oxygen requirements of aquatic life with emphasis on Canadian species. Rev. J. Fish. Res. Board Canada 32, 22952332.

Dawes, C.J., 1981. Marine Botany. A WileyInterscience Publication, USA

Desikachary, T.V. 1959. Cyanophyta, ICAR, New Delhi

Gabche, C.E and Smith, V.S., 2002. Water, salt and nutrient budgets of two estuaries in the coastal zone of Cameron. West Afr. J. Appl. Ecol. 3, 69-89.

Harsha, T.S and Malammanavar, S.G. 2004. Assessment of phytoplankton density in relation to environmental variables in Gopalaswamy pond at Chitradurga, Karnataka. J. Environ. Biol. 25, 113116.

Joseph, S and Ouseph, P.P. 2010. Assessment of nutrients using multivariate statistical techniques in estuarine systems and its management implications: a case study from Cochin Estuary, India. Water Environ. J. 24, 126-132.

Jouenne, F., Lefebvre, S., Veron, B and Lagadeuc, Y. 2007. Phytoplankton community structure and phytoplankton production in small intertidal estuarineBay ecosystem. Mar. Biol. 151, 805825.

Jouenne, F., Lefebvre, S., Veron, B and Lagadeuc, Y. 2007. Phytoplankton community structure and phytoplankton production in small intertidal estuarineBay ecosystem. Mar. Biol. 151, 805825.

Martin, G.D., Vijay, J.G., Laluraj, C.M., Madhu, N.V., Joseph, T., Nair, M., Gupta, and G.V.M., Balachandran, K.K. 2008. Fresh water influence on nutrient stoichiometry in a tropical estuary, Southwest coast of India. Appl. Ecol.
Environ. Res. 6, 57-64.

Muhammad, A., Salam, A., Sumayya, I., Tasveer, Z.B., and Qureshi, K.A. 2005. Studies on monthly variations in biological and physico-chemical parameters of brackish water fish pond, Muzaffargarh, Pakistan. J. Res. (Sci.) $16,27-38$

Muhammad, A., Salam, A., Sumayya, I., Tasveer, Z.B., and Qureshi, K.A. 2005. Studies on monthly variations in biological and physico-chemical parameters of brackish water fish pond, Muzaffargarh, Pakistan. J. Res. (Sci.) $16,27-38$

Of general water quality: a comparison with SASS 5. Water SA 30, 325-332.

Omstedt, A., Edman, M., Anderson, L.G., and Laudon, H. 2010. Factors influencing the acid-base $(\mathrm{pH})$ balance in the Baltic Sea: a sensitivity analysis. Tellus 62, 280-295.

Perumal, N.V., Rajkumar, M., Perumal, P., and Rajasekar, K.T 2009. Seasonal variation of phytoplankton diversity in the Kaduviyar estuary, Nagapattinam, South east coast of India. J. Environ. Biol. 30, 1035-1046.

Pielous, E.G. 1966.: The measurement of diversity in different types of biological collections. J. Theor. Biol., 13, 131-144.

Reavie, E.D., Jicha, T.M., Angradi, T.R., Bolgrien, D.W and Hill, B.H., 2010. Algal assemblages for large river monitoring: comparison among biovolume, absolute and relative abundance metrics. Ecol. Indic. 10, 167-177.

Rey, P.A., Taylor, J.C., Laas, A., Rensburg, L and Vosloo, A., 2004. Determining the possible application value of diatoms as indicators of general water quality: a comparison with SASS 5. Water SA 30, 325-332.

Rojo, C and Rodríguez, J. 1994. Seasonal variability of phytoplankton size 
structure in a hypertrophic lake. J. Plankton Res. 16 (4), 317-335.

Sankaranarayanan, V.N. and Qasim, S.Z., 1969. Nutrients of Cochin backwaters in relation of environmental characteristics. Mar. Biol. 2, 236-247.

Sarma, V.V., Sadhuram, Y., Sravanthi, N.A and Tripathy, S.C. 2006. Role of physical processes in the distribution of chlorophyll-a in the Northwest Bay of Bengal during pre- and post-monsoon seasons. Curr. Sci. 91, 1133-1134.

Saxena, A and Shrivastava, P. 2001. Primary production by phytoplankton in a sewage fed lake and energy transformation to fish yield. Pollut. Res. 20, 613-617.

Schelske, C.L. and E.F. Stoermer. 1971. Eutrophication, silica and predicted changes in algal quality in Lake Michigan. Sci., 173, 423-424.

Shannon, C. E and W. Weaver.1949. The Mathematical Theory of Communication. University of Illinois Press, Urbana, Illinois. 144pp.

Sharma, R.K and Rathore, V. 2000. Pollution ecology with reference to commercially important fisheries prospects in rural- based water body: The Lake SarsaiNawar, Etawah (Uttar Pradesh). Pollut. Res. 19, 641-644.

Sharma, S., Dixit, S., Jain, P., Shah, K.W and Vishwakarma. R 2008. Statistical evaluation of hydrobiologicalparmeters of Narmada water at Hoshangabad City, India. Environ. Monit. Assess. 143, 195-202.

Simpson, E. H. 1949. Measurement of diversity. Nature, 163: 688.

Soininen, J., Paavola, R., Kwandrans, J and Muotka, T. 2009. Diatoms: unicellular surrogates for macroalgal community structure in streams? Biodivers. Conserv. 18, 79-89.

Varis, O., 1991. Association between Lake Phytoplankton community and growth factors-a canonical correlation analysis. Hydrobiologia 210, 209-216.

Zepp, R.G., 1997. Interactions of marine biogeochemical cycles and the photodegradation of dissolved organic carbon and dissolved organic nitrogen. In: Gianguzza, A., Pelizzetti, E., Sammarkano, S. (Eds.), Marine Chemistry. Kluwer, London.

\section{How to cite this article:}

Sudhakaran Mani, Ramamoorthy Duraisamy, Savitha Veeraragavan and Rajesh Ramasamy. 2017. Study on the Influence of Water Physico Chemical Properties on Phytoplankton Population in Kirumampakkam and Korkadu Lakes, Pondicherry Region, India. Int.J.Curr.Microbiol.App.Sci. 6(11): 3107-3114. doi: https://doi.org/10.20546/ijcmas.2017.611.364 